\title{
Developing Family Mediation in Finland: The Change Process and Practical Outcomes
}

\author{
Vaula Haavisto
}

\section{Contents}

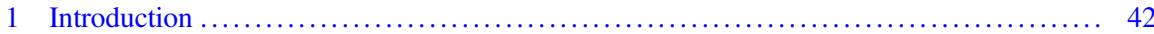

2 Family Mediation and Family Conflicts in the Service System .................... 43

3 Methodological Questions in Developmental Mediation Research ................... 46

3.1 Development: Top-Down or Bottom-Up? ........................... 46

3.2 Learning: Adopting Existing Knowledge or Creating New? ................... 47

4 The Developmental Process in Project Fasper ................................... 48

4.1 The Mapping of Terrain ........................................... 49

4.2 Developing and Implementing Family Mediation Practices .................... 49

4.3 Distributing the Created Models ...................................... 52

4.4 Where to Go Next—Consolidating Family Mediation Nationwide .............. 52

4.5 Evaluating the Developmental Process ................................ 53

4.5.1 Developmental Work in a Multi-Organisational and Multi-Professional

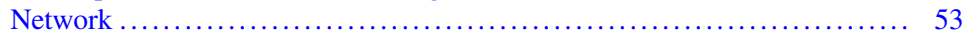

4.5.2 Developmental Work as Collaborative Concept Formation ................ 54

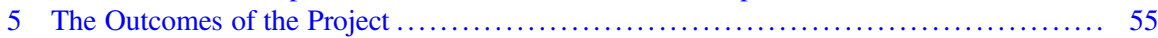

5.1 The Process Model for Family Mediation .............................. 55

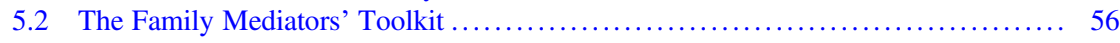

5.3 The Service Model for Organising Family Mediation in a Multi-Organisational

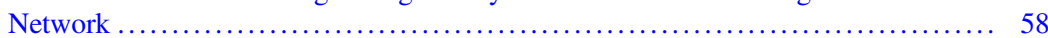

5.4 The Model for Elementary Training of Family Mediators .................... 59

5.5 Evaluating the Benefits of the Implemented Family Mediation Model ............. 61

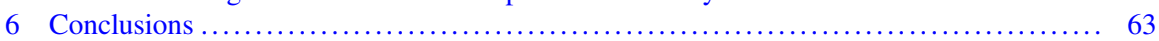

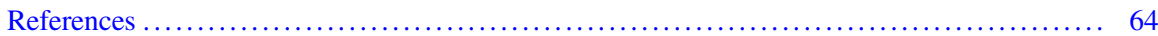

\begin{abstract}
In this article, I discuss the process and outcomes of a successful developmental project on family mediation in Finland. Family mediation is a municipal service available for divorcing parents who cannot agree on child custody matters. In the Marriage Act of 1987, prerequisites were made for family mediation as an early intervention to help families in conflict. In practice, only few parents used the service. Moreover, the concept of mediation was fluid and diffuse and practitioners working
\end{abstract}

\footnotetext{
V. Haavisto $(\square)$

Faculty of Educational Sciences, University of Helsinki, Helsinki, Finland

e-mail: vaula.haavisto@sovittelu.com
} 
with divorce families understood and applied mediation in different ways. Moreover, often family mediation was not undertaken as a distinct process. In the article, I describe the developmental work done in a project called "Fasper" whose aim was to change the present situation by exploring the concept of family mediation and producing new mediation models, practices and tools for family mediators. Following the methodological starting points of Developmental Work Research, the project did not offer a ready-made, top-down model for family mediation. Instead, practitioners studied divorce services and developed, tested and implemented new models and practices for family mediation. It is important to continue this work and bring it to the national level in order promote major changes in the system.

\section{Introduction}

In 2009, the Finnish Forum for Mediation-a non-governmental organisation promoting mediation in different fields of society—initiated a multi-disciplinary project to study and develop family mediation in Finland. The project was called Fasper, which was an abbreviation from Finnish words meaning facilitative family mediation.

Municipalities in Finland are required under the Marriage Act 1987 to provide family mediation as a voluntary service for families in dispute (Avioliittolaki 411/1987). The service is free-of-charge. The purpose of family mediation is to find a solution for the conflicts among family members through discussions and negotiations. Family mediators are usually employees of family counselling, child protection or other social welfare services who are assigned the task by the municipal social welfare boards. Family mediation is also available at other entities authorised to provide family mediation services, which mainly consists of the family counselling centres operated by the Evangelical Lutheran Church of Finland.

Focusing on the Marriage Act, one could assume that family mediation was an established service, available for all citizens. However, both the Parliamentary Ombudsman in her decision (Eduskunnan oikeusasiamiehen päätös 2004) and Sami Mahkonen in his investigation (2008) had reported just the opposite: in the municipalities, the organisation of family mediation varied a lot, there was a disruptive overlap between family mediation and different forms of family counselling, and the service was often poorly available. Project Fasper was launched to find solutions to these problems and study the potential of family mediation to serve as a central resolution method for family conflicts.

Project Fasper was conducted in 2009-2014 by a group of researcherinterventionists employed by the Finnish Forum for Mediation: a project manager, researcher and a senior researcher-the last one only for the first 3 years of the project. This group was supported by a scientific leader, a university professor in 
social work. While writing later in the article about "we", I refer to this group of researcher-interventionists who was responsible of the research and the interventions made in the project. As a project manager, I was part of the group.

Our study represents interventionist studies, where the focus is on studying through experimenting: changing human activities by experimenting and evaluating the new activities. The project followed the methodological starting points of Developmental Work Research (DWR), ${ }^{1}$ an approach in which researcherinterventionists guide a community in its efforts to develop and transform practices (Engeström and Sannino 2010). Related with the tradition of Action Research (Lewin 1948), the potential new activities are in a similar vein pursued in collaboration with the researchers and practitioners. In project Fasper, this meant close collaboration between researcher-interventionists and front-line employees.

In this contribution, I will begin by describing the starting points of the projectthe fluid concept of family mediation and the unorganised practices. After that, I will raise some theoretical concerns about the methodology needed in promoting change and learning in such complex systems as family mediation services. That will be followed by an overview of the developmental process in project Fasper. Some of the concrete outcomes-hence, the models created in the project-are presented. Finally, I will discuss the main conclusions concerning change and collaborative learning in developing mediation.

\section{Family Mediation and Family Conflicts in the Service System}

In Finland, a mutual settlement between the parents is considered the primary course of action after divorce or separation. According to the Child Custody and Right of Access Act 1983, the agreement parents make on the custody, living arrangements, visiting rights and maintenance of their child can be registered by the social board in a child's home municipality, allowing the agreement to be executed (Laki lapsen huollosta ja tapaamisoikeudesta 1983). In confirming the agreement, the best interests of a child must be considered. The child welfare officers-usually social workers or lawyers by training-who register the agreements can only register or refuse to register the parents' agreement, not alter it. If the parents cannot agree on children's matters, the municipal family mediation is one option available for them. ${ }^{2}$

\footnotetext{
${ }^{1}$ DWR is a methodology for simultaneous research and development in workplace settings created at the University of Helsinki, see Engeström (1995), Engeström (2005). Guided by CulturalHistorical Activity Theory with the origins in Russian social psychology, see Vygotsky (1978), Leontjev (1978), it is a theory-driven method for analysing developmental possibilities in complex, interacting systems. The approach is guided by Engeström's theory of Expansive Learning (1987), which emphasises learning as creation of new knowledge and practices.

${ }^{2}$ In addition to municipal family mediation, also court-connected mediation in custody and contact disputes is available for parents. This form of mediation is discussed in Kirsikka Salminen (2018).
} 
The legal framework for family mediation comes from chapter 5 of the Marriage Act of 1987. Additionally, the Social Welfare Act sets the requirement for municipalities to organise family mediation (Sosiaalihuoltolaki 1301/2014). According to the Marriage Act, "disputes and legal matters arising in a family should primarily be settled in negotiations between the family members and decided by agreement". The family mediator's task is to "render assistance and support, upon request, when disputes arise in a family". An amendment was made in 1996, which says that family mediators may render assistance and support also "in the event that disputes arise as to compliance with a court order or an agreement on child custody and right of access" (Avioliittolaki 411/1987, chapter 5, section 20).

Section 21 of the chapter states the following: "A mediator shall aim for a confidential and open discussion between the family members. He or she shall aim for a consensus as to how to solve the disputes in the family in the best possible way for all the persons concerned." In addition, it is ruled that " $[\mathrm{t}]$ he mediator shall pay special attention to securing the position of the minor children in the family" (section 21, subsection 2) and that "[t]he mediator shall assist the persons concerned in concluding agreements and in other measures necessary for the settlement of disputes" (section 21, subsection 3). The rest of the sections deal with the monitoring, planning and controlling of family mediation; the authorization of service producers other than municipal authorities; as well as the duty of secrecy of the mediator, among other things.

As can be seen, the wording of the Marriage Act is broad and covers, in principle, all possible conflicts between different family members. In practice, family mediation has been interpreted to cover situations where a couple is divorcing or has divorced and they are in dispute over their children. Still, there is quandary whether mediation should be offered for spouses who are contemplating the possibility of a divorce or only for those who have already decided to get divorced. Similarly, there may be different interpretations about the content of family mediation: do there have to be a dispute over the children or can family mediation be a more therapeutically oriented assistance for dissolving the couple relationship.

For many years, the field of Finnish family mediation was blurred and discontinuous. The municipalities had no uniform guidelines on how to arrange the mediation services and very often the service was non-existing-almost a dead letter. No official statistics on how many municipalities offered family mediation were available. It is thus no wonder that Finnish parents only seldom had heard of family mediation services or knew what mediation could offer them (Mahkonen 2008; Eduskunnan oikeusasiamiehen päätös 2004; Karvinen-Niinikoski and Pelli 2010). If they entered the process, they were not necessarily aware of it (for the problems of the overly broad definitions of mediation, see Nylund (2018)).

Correspondingly, professionals working with divorced families were confused with the concept and practices of family mediation. In the interviews conducted in the early phase of project Fasper (see 4.1), professionals working with divorced families were asked how do they see family mediation, where does it take place, and do they mediate by themselves. Here are some quotes from the professionals: 
Often it [family mediation] is kind of legal term, a work that has to be included in the statistics. Here at the family counselling centre, we don't compile statistics on family mediation. It is only a thin red line what is mediation and what is something else. Much of the work done here in family counselling is mediation, but it is included in the statistics as some other type of work, for example, guidance and consulting or family therapy. It becomes as part of the working process, mediation is inside the working process. I could imagine that family counselling workers of my generation see mediation as a bit superficial. Psychologist at a family counselling unit, August 2010.

Here at the family counselling unit I try to mediate a bit, find some connections between the parents, but it is not any real mediation. In our municipality it is very confusing, the clients roll around in this system. There is no clarity in this swirling system. Social worker at a family counselling unit, May 2010.

I think mediation is mostly giving information, not therapy in any way. Giving information and considering the child's situation. Social worker at a family counselling unit, May 2010.

I get acquainted with mediation weekly when I meet divorced parents who cannot agree with each other. I see that mediation is sprinkled into several job descriptions, into social work, the work of child welfare officers, family work in early child protection, family counselling units here in municipality and in the church. A systematic way of working is missing, but we can use the already existing tools. Senior social worker at a family support unit, October 2010 .

The answers described ambivalence about what kind of work is considered as mediation and whether it differs from other services, such as counselling and guidance. They showed that family mediation was not recognised and organised as a discrete process. As a result, individual professionals used counselling, therapy and social work techniques under the generic label of mediation. With a lack of qualifying training for mediators, the concept of family mediation was under-developed and theoretically vague (Karvinen-Niinikoski and Pelli 2010; Mattila-Aalto et al. 2012).

At the same time, the service system for divorce families faced severe difficulties. There were several services available, but nobody knew or could predict how the clients moved in the system and used the services. Despite of several services, the parents in conflict over their children were not helped. The service system became overloaded and the frontline service providers exhausted and frustrated with not being able to help (Karvinen-Niinikoski and Pelli 2010; Mattila-Aalto et al. 2012; Julkunen and Karvinen-Niinikoski 2014).

The big number of unresolved parental conflicts had resulted in parents seeking help from all available services, leading to high public costs of custody disagreements (Hämäläinen 2011). Parents' disagreements produced a big number of submitted child welfare notifications to the authorities (Toimiva lastensuojelu -selvitysryhmän loppuraportti 2013). Several distinct service producers formed a disconnected field, which-at its worst—escalated parental conflicts instead of helping to solve them (Mattila-Aalto et al. 2012). If the parents could not settle their disagreements, there were guided from the social welfare services directly to the courts. It was clear that the zone of dispute resolution around the courts was missing. These observations suggested that re-considering the ideas and practices of 
family mediation could generate a new out-of-court way of handling and resolving parental conflicts.

In this situation, the Finnish Forum for Mediation initiated project Fasper to develop, test and implement new content and practices for family mediation- to give a fresh start for family mediation, so to say. The 5-year project started with six municipalities and their collaborators to create a unified approach to family mediation as a short-term, structured intervention for parents in conflict over their children. ${ }^{3}$ The aim was also to develop a new service model that would help integrating family mediation into the service system so that it would be easily available for divorcing parents. In addition, one aim was to create a model for family mediators' elementary training. The project did not offer a ready-made, top-down model for family mediation to be locally implemented. Instead, it invited the practitioners to study the present divorce services and parents' needs and to develop, test and implement new models and mediation practices to better serve the parents' needs (Haavisto et al. 2014).

\section{Methodological Questions in Developmental Mediation Research}

\subsection{Development: Top-Down or Bottom-Up?}

"Implementation - how great expectations in Washington are dashed in Oakland" starts the title of the classic book by Jeffrey Pressman and Aaron Wildavsky (1984). They point to the problematic nature of and difficulties in promoting change and development: the reluctance of organisations to approve intended change and adopt new practices, as well as the failings of or alteration to planned changes. Is change something that can be adopted from above or does it have to be generated from within? Is it once-and-for-all or a series of small improvements, and finally, is it planned or emergent?

The early studies of policy implementation recognised the gap between legislative intent and bureaucratic action (Palumbo and Calista 1990; Bardach 1980; Pressman and Wildavsky 1984). Researchers tried to make sense of why the serious intents did not materialise when put into practice. The metaphor of gap between intent and outcome had its roots in a top-down model of implementation, which considered implementation to be the simple, purely technical execution of a policy maker's or legislator's intention, in which the rules are implemented as they were intended (Mazmanian and Sabatier 1983). A reverse perspective on implementation started to emerge when implementation was understood as a series of change efforts that emerge from within an agency or community, drawing on local knowledge and lived experiences. According to the bottom-up model, implementation is not

\footnotetext{
${ }^{3}$ For definitions of family mediation as a distinct process, see e.g. Parkinson (2014), Roberts (2008), and for mediation in general, Vindeløv (2007).
} 
technical exercise, but rather a continuous, usually local project in which the reform is adjusted to local needs (Palumbo and Calista 1990; Eisenstein et al. 1988; Majone and Wildavsky 1984).

The acknowledged fruitlessness (Palumbo and Calista 1990) of these two opposing approaches has led to attempts to try to overcome the simplistic interpretations of the implementation problem. According to Yanow (1990), top-down policies are interpreted and given meaning-understood, explained and altered-from the bottom-up by the implementers. This potential for new and emergent urges to connect the issues of learning with the implementation of change.

\subsection{Learning: Adopting Existing Knowledge or Creating New?}

In studies of the top-down perspective on the implementation of change, learning could be best understood as adopting new rules, policies or practices (Haavisto 2002). Especially in the context of courts and law, adopting new rules has traditionally been the major form of learning. Learning is regarded as a non-problematic result of pouring the necessary information into those who are to implement it. The bottom-up perspective emphasising the discretion of local implementers, suggests that the implementation process is subject to constant modification and adjustments in goals, strategies and practical execution. According to this view, learning seems to be a continuous process of adaptation, where implementers learn to fit the policy to local needs (Haavisto 2002).

In addition to adopting and adapting as forms of learning, the implementation of change can be viewed as a process that also contains the questioning of current cultural models and production of novel local solutions. This potential for new and emergent is elementary in the theory of expansive learning (Engeström 1987). In expansive learning, people are not required to adopt change nor compelled to adapt to them. Instead, they initiate and seek new solutions and actively make sense of the situation they are in. Expansive learning is not about choosing between ready-made alternatives, nor merely re-defining something already known. It involves learning new forms of activity that are not yet there (ibid.).

The focus of this article can be described with the following four-square matrix (Fig. 1), where the horizontal dimension concerns whether learning is seen as the appropriation of culturally given knowledge or as the creation of culturally new knowledge. The vertical dimension determines whether we focus on development taking place as top-down or bottom-up. The interest of this article is on the bottomup implementation of changes and on the learning of local solutions that go beyond existing traditions and models.

Focusing on the local implementation of changes and the creation of novel solutions raises a more finessed question about the learning taking place. If the practitioners are creating and learning something that is not yet there, how is the new 
Top-down implementation of changes

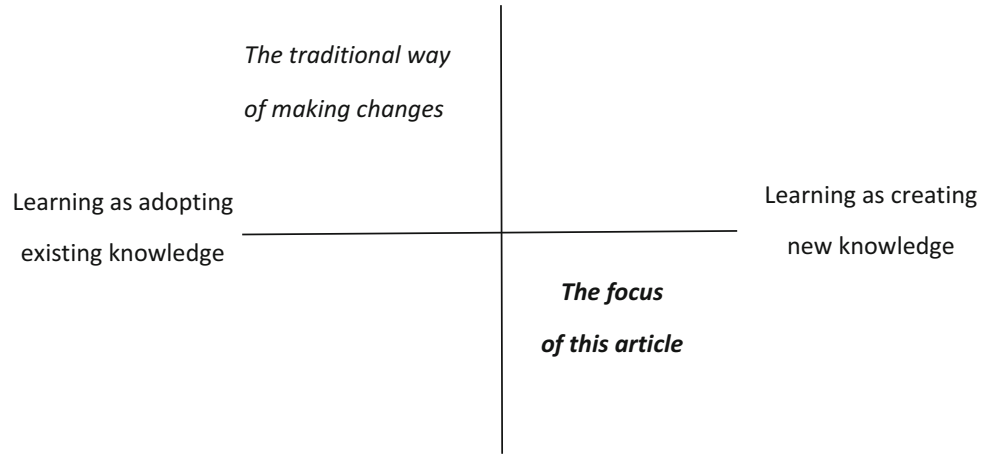

Bottom-up implementation of changes

Fig. 1 The focus of this article

generated? Does it start as a creation of concepts and abstract models or does it start from creating and establishing new practices and concrete outcomes?

These questions are in the nucleus of the studies of concept formation and conceptual change, relevant to our understanding of change and learning. Concepts are traditionally understood as abstract, cognitive entities that are determined by an explicit definition (Greeno 2012). In addition to this kind of formal concepts, we can also distinguish functional concepts (Greeno 2012) or concepts of practice (Hutchins 2012). These are usually formed within and between complex activities, and they are typically collective (Engeström and Sannino 2012). They help people to organise their understanding of what they are doing (Greeno 2012).

Functional concepts develop within and from local practices. The changes pursued in project Fasper can be seen as collective learning and an effort of functional concept formation. The functional concepts are challenged, re-formulated and executed in practice. As Engeström (2014) states, collective concept formation is typically a long process in which the concept itself undergoes multiple transformations and partial stabilisations. This type of creation necessarily transcends the boundary between the mental and the material. It is both an endeavour of collective learning and a creative process of generating something culturally new (Engeström 2014).

\section{The Developmental Process in Project Fasper}

Following the principles of DWR, project Fasper aimed at local knowledge production and transformative learning through creation of new practices. In DWR, every participant's reflections and professional expertise are of genuine interest and brought forward to the advantage of both the learners and the activity they develop (Engeström 2009). Researcher-interventionists guide a community in its effort to 
develop and transform practices. The learners construct together their interpretations of events by searching for new meanings, reinterpreting phenomena and creating new knowledge, and, finally, putting the ideas into action (Engeström and Sannino 2010). In its active years 2009-2014, project Fasper followed the cycle model of expansive learning, consisting of the following phases: questioning and analysing the present activity, modelling the new activity, testing, implementing, and consolidation (Engeström 1987; Engeström and Sannino 2010).

In six municipalities around the Helsinki metropolitan area, practitioners from different organisations gathered together to study and develop family mediation. Social workers, child welfare supervisors, family workers, psychologists, family therapists, family counsellors, attorneys and judges participated in the project. They were organised in two similarly-composed local learning networks that met separately 12 times during years 2011-2012. Every session, with an average of 14 participants per session, lasted approximately $3 \mathrm{~h}$. The two networks were given similar learning tasks by the researcher-interventionists.

\subsection{The Mapping of Terrain}

The objective of project Fasper was defined widely on purpose: the general aim was to study the possibilities of family mediation to resolve families' conflicts and promote family mediation practices that could facilitate parents to resolve their conflicts by themselves (Karvinen-Niinikoski and Pelli 2010). The project started with "mapping of the terrain". The researchers interviewed 90 professionals working with divorced families to uncover how the services were organised in the municipalities participating in the project and how the professionals understood family mediation. The picture given by the interviews as to the local conditions was in line with the previous national findings (Eduskunnan oikeusasiamiehen päätös 2004, Mahkonen 2008). Family mediation was not available as a distinct process (except in one of the participating municipalities) and there was no jointly shared understanding of mediation. Many of the interviewed said they were doing "kind of mediation"-in other words, they used different kind of working methods under the generic label of mediation. The conceptual unclarity resulted in different kind of practices and perceptions. Can one come to mediation alone or together with the ex-spouse? What does the mediator do in mediation? What can he or she not do? Is all counselling and guidance the same as mediation? (Haavisto et al. 2016).

\subsection{Developing and Implementing Family Mediation Practices}

After mapping the terrain, a landscape of family mediation in Finland opened. The service system was scattered, divorced parents occupied heavily the service system, 
family mediation was not easily available, and there was no joint understanding of its content and execution (Haavisto et al. 2016).

In our hands, there were a skein in which family mediation was a formal and authoritative activity regulated by law, but the practice appeared inconsistent and scattered. We faced a double bind: we could not train a ready-made mediation model for the practitioners, as it would have inevitable been a pre-given, top-down model, the establishing of which would have been highly uncertain. On the other hand, we could not simply start to develop new practices for family mediation, as the participants did not have any shared knowledge or concept of mediation on which to base the developmental work.

The tension could not be resolved by offering mediation training, neither by creating directly a new concept for family mediation. We could not choose between the clear-cut top-down and bottom-up models of implementing change, but had to find a third way of proceeding. We started to search for a way of developing, where the increasing of participants competence in mediation (the adoption of knowledge) and the local development of practices and service models (the creation of new knowledge) were intertwined as a process where the one feeds the other. The project progressed as an interplay between mediation trainings and the local developmental network sessions.

The local learning networks were organised on geographical basis so that neighbouring municipalities started to work together in spring 2011. In their first two network sessions, they examined the local divorce service system, both the present and historical situations. They found that divorced families move around the local services without anyone knowing their route and anyone having the big picture of their situation. They focused on the failure of the service system to meet the needs of divorcing parents in conflict and recognised this scattered service system as their shared problem space in need of change. This kind of questioning of the present system seems to be an elementary prerequisite for change and transformation (Bergman-Pyykkönen 2017).

After the sessions of examining and questioning, we organised the first mediation training. It was a one-day training to introduce mediation as a conflict resolution method in different areas of society and different kinds of conflicts. After that, we organised a more detailed three-day training in family mediation to deepen the understanding and practicing of family mediation as a distinct process. We invited family mediator and trainer Lisa Parkinson from the United Kingdom as the trainer. We considered important that the trainer was well-experienced not only in mediating family conflicts, but also in producing mediation models and practices.

After the training, we continued working in local networks, the goal being to test in practice the things learned in training. We had constructed interconnections between training and local development: the participants anticipated the training by addressing questions they needed to get answers. In the network sessions after the training, the given concepts and models were to fit the local conditions. Network sessions three through seven were to produce the new concept of family mediation and prepare for testing the paradigm and new tools. The participants tackled with 
questions such as how does mediation process in our area look like and how is the new family mediation service organised as part of the larger divorce service system.

The first trials of new methods were conducted in Spring 2012. One of the local networks made intensive experiments and, finally, they had 15 family mediation processes conducted, all documented by the researchers. ${ }^{4}$ In the other network, the leap from adopting knowledge to the local creation of new mediation practices appeared more demanding and slow. In network sessions eight and nine, the new practices and emerging service system were evaluated through the experiences gained in the experiments.

The local trials were intermitted by a further training when Lisa Parkinson gave a workshop for those practitioners who participated in the mediation experiments. The workshop was based on pre-assignments in which the participants reported their observations in the experiments to the trainer and disclosed what kind of further knowledge they needed. The workshop discussions were documented for the participants as training material to be available when later needed. After the training, the experiments continued with new mediation cases.

The experimenting phase in project Fasper took approximately 1 year. During that period, the family mediation process and mediator's toolkit were gradually developed. As a result, from the discussions in the network sessions there started to emerge a more common understanding of what mediation could be about, what is the focus of family mediation, and what kind of practices and tools are needed in mediation. At the same time, the first envisions about how family mediation could be more accessible and available than before came to light, along with how the mediation service could be produced in a multi-organisational network and how the new mediation service could be integrated into the existing service system. The last network sessions 10 through 12 included enriching and evaluating the tested models. Examples of the created new models and practices are presented in the next chapter.

The new family mediation service was officially implemented in spring 2013 when a multi-municipal unit for family law matters was built and started to coordinate family mediation service on the area. The year 2013 was time for consolidating the new mediation practices. The interventions and network sessions organised by the researcher-interventionists finished, but the participants organised necessary guiding instruments of their own. The family mediators met regularly in team meetings, and they created also a form of competence development which they called "family mediators' sparring afternoons".

\footnotetext{
${ }^{4}$ After the mediation process was finished, the parents and mediators were interviewed; parents separately, the co-mediators together. A part of the mediation sessions was also audiotaped with the parents' permission.
} 


\subsection{Distributing the Created Models}

The implementation and consolidation of the created models raised the question how the created models could be distributed to other municipalities as well. A training model for family mediators' elementary training was piloted in the fall 2013.

We organised a planning group of seven people - two researcher-interventionists and five practitioners from the project-who at first started to co-create the contents for the training and then finally executed it as eight-days training for workers who had not participated earlier in project Fasper, but who were interested to start as family mediators.

After the pilot training, we were granted an allowance to produce four corresponding elementary trainings for family mediators around the country. This meant that approximately 80 professionals completed the elementary training, supported by the financial aid from the government. Since then, family mediators' elementary training has been organised randomly, mainly in collaboration with summer universities.

\subsection{Where to Go Next-Consolidating Family Mediation Nationwide}

The first step to establish family mediation largely in municipalities is to organise it as a distinct process - as was done in project Fasper. If family mediation is palatalised as minor or marginal method or working approach, "mediation-kind-of work", family mediation cannot reach its full potential.

The second step in municipalities should be acquiring training for the employees working as mediators. When the demand for family mediation grows, it is important to have well-trained, competent mediators.

The third step is to integrate family mediation into the family service system and organise the service provision in a way that suits for local conditions. The experiences in project Fasper convinced researchers and practitioners that mediation is possible to organise and provide in collaboration of several municipalities and other service producers, such as the church counselling units and NGOs providing family and divorce services.

The municipalities can support the establishing of family mediation by defining the referral system to mediation, providing mediation actively and by making informative presentations and leaflets about family conflicts and mediation.

In addition to the municipal measures, national procedures of consolidation are needed. The role of the regional state administrative agencies should be strengthened in planning, steering and monitoring the execution of family mediation in municipalities. Similarly, the role of the ministry of social welfare and health in promoting mediation needs to be reconsidered. Also, the chapter ruling family mediation in the Marriage Act needs updating. 
The municipal family mediation offers the cost-free mediation service for parents, guaranteed by the present legislation. In the future, there will be reforms in the provision of social services, which will transfer the services from municipalities to provinces. This will probably open the service production also for the private producers.

In the future, we need common rules concerning the qualification requirements of family mediators and the training required. We need to consider whether the provision of family mediation should be subject to license or authorisation. This question may actualise if also private family mediation markets will emerge. We need to consider should there be an acceptation system for family mediators, which would both accept competent mediators and monitor how do they maintain and develop their competence. In Finland, we are at our early steps of professionalisation and quality control.

\subsection{Evaluating the Developmental Process}

\subsubsection{Developmental Work in a Multi-Organisational and Multi- Professional Network}

In project Fasper, family mediation was developed as multi-organisational collaboration including several service units of the municipalities, family counselling units of the church, courts and private law firms - despite of the fact that mediation service was the statutory responsibility of municipalities. Our initial presupposition was that gathering together all the local service providers around parental conflicts would benefit the developmental work and result as higher quality of the dialogue. We also thought that the collaborative effort would increase the consciousness about family mediation in all participating organisations, which would later promote adequate referral system.

The participants of DWR informed projects construct new meanings, re-interpret and constitute new ideas (Engeström 2009). In the context of family mediation, the elementary question was how can the practitioners with different professional backgrounds create a unified, shared understanding of family mediation. How do they negotiate joint understanding of their new task as family mediators and how do they construct new professional identities as mediators?

The researcher of project Fasper, Marina Bergman-Pyykkönen, showed in her study (2017) on interprofessionality in the project how bringing together practitioners with different organisational and professional backgrounds to collaborate outside the shelters of their institutions was a demanding effort. It contributed, however, to the emergence of a discursive space allowing for diversity in knowledge. As there were representatives of different professions in the workshops, it compelled them to argue and explain their ideas more thoroughly than if the participants were own colleagues with similar backgrounds (Bergman-Pyykkönen 2017). 
The intersection of diverse practices belongs to all the intersecting practices, but is not defined by any one of them. This was especially true with family mediation, which was not "a property" of any special profession, but instead, a no-man's land. The ambiguous nature of boundaries activated dialogue, but still required special methods and tools to facilitate communication between the participants. The interprofessional collaboration in Fasper increased talk at the boundaries and the transparency and thoroughness of discussions in the workshops, but in order to happen, demanded not avoiding confrontations, but using them to explore and promote dialogue (Bergman-Pyykkönen 2017). In the analysed two learning networks of project Fasper, the first one (called the client-centred network) avoided confrontations and the dialogue got closed, whereas the second one (called the service systemcentred network) used confrontations to explore and promote dialogue (BergmanPyykkönen 2017). The latter one became the spearhead of development in the project.

Similarly, powerful discursive tools were needed to structure a shared problem space and to envision the future. In her study, Bergman-Pyykkönen found metaphors, anecdotes and models as discursive tools used by Fasper participants and recognised them as elementary for understanding learning in multi-professional groups and collective developmental efforts.

\subsubsection{Developmental Work as Collaborative Concept Formation}

The developmental work done in project Fasper was a collaborative effort to create new concepts for family mediation. In his analysis of the dynamics of concept formation, Engeström (2014) found two main directions: concept formation with the name in the lead and concept formation with the practice in the lead. In the first case, there exists a name (a concept), but only a vague idea of what it represents. Collaborative concept formation is a search for contents for the name. In the latter case, concept formation moves the opposite order with the novel practice in the lead, but no name for it (Engeström 2014).

In our previous study on the concept formation (Haavisto et al. 2016), we found that, in general, project Fasper was an example of concept formation with a name in the lead. The concept of family mediation was recognised and defined by the law, and in the project, new mental and material content for it was created. The first question of the multi-professional and multi-organisational learning network was "what family mediation is about?" When the concept formation proceeded, the practical question was "how family mediation is organised?" Later, when the models for family mediation process and service organisation were defined, there emerged a need to ask more specifically "how and with what tools family mediation is conducted?"

Proceeding with the name in the lead does not, however, mean that concept formation was only mental, i.e., producing textual definitions of the phenomena and abstract content for the concept. In fact, family mediation could not be conceptualised as such-that is making universal definitions at a desk-but it 
occurred when the practical questions of organising and conducting family mediation were answered and resolved. Concept formation is predominantly a collaborative process, in which the concept gets new practical and material manifestations while developing further. The new tools implemented and models for family mediation process, service organisation and mediators' training were all manifestations of the emerging concept of family mediation.

\section{The Outcomes of the Project}

In this chapter, the practical outcomes-the models created-are presented. In project Fasper, the following models were created, implemented and established locally:

- The process model for family mediation

- The family mediator's toolkit

- The service model for organising family mediation in a multi-organisational network

- The model for eight-day elementary training for family mediators

In the following, I will at first present the process model for family mediation, in order to give reader a general picture on how the family mediation process is conducted. After that, I will give an overview of the content of mediator's toolkit and describe more closely one special tool used by the mediators, the ecogram. Then I will depict the service model for organising family mediation and, finally, present the training model for family mediators' elementary training.

\subsection{The Process Model for Family Mediation}

The process model implemented in project Fasper is described in Fig. 2. In this form, the process is established in some of the participating municipalities, and it is also the model disseminated in family mediators' elementary training. The model consists of preliminary meetings separately for both parents and usually three appointments with both parents present. The number of joint meetings may vary, keeping in mind, however, that mediation is to be short-term. In this model, there are two mediators in all meetings, also in preliminary individual meetings. If the parents reach an agreement, they are often offered a possibility to come to a follow-up meeting to discuss how the new arrangements are working.

The total duration of the process varies approximately from 3 weeks to 2 months, according to the pace favoured by the co-mediators who set the timetable. In this temporal dimension, the municipal family mediation differs from the Finnish courtconnected mediation of child custody disputes, where the mediation is aimed to be handled in one day. A future research would be needed to see if there is any 


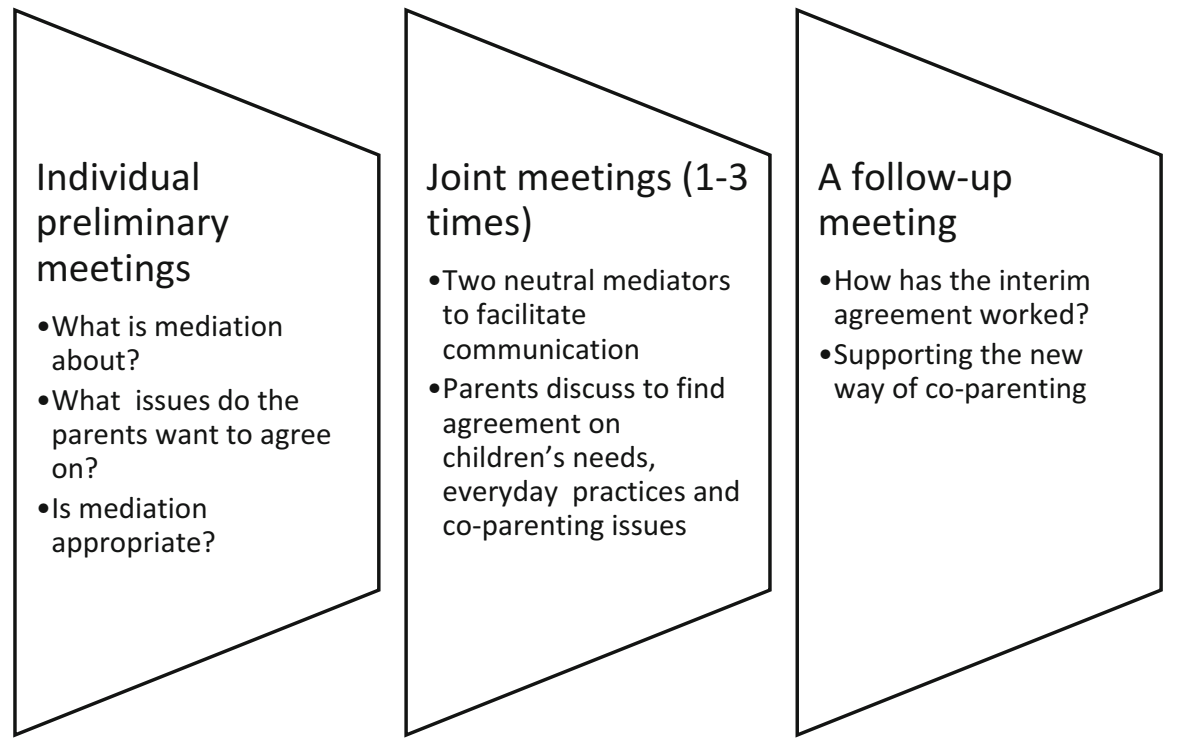

Fig. 2 The process model of family mediation in project Fasper

verification to our assumption that the prolonged process might better support and give room to the learning process of the parents and to the gradual growth of trust between them (see also Nylund 2018).

\subsection{The Family Mediators' Toolkit}

Family mediators' toolkit is a set of different kind of tools and models needed in conducting the mediation process in interacting with the parents and managing and resolving the conflict. We have distinguished two set of tools: "perceiving tools" and "technique tools". Perceiving tools are for increasing understanding and knowledge about the problem at hands; technique tools are for solving those problems.

Perceiving tools can also be called "what is this about" tools, as they are different kind of models, figures, metaphors, etc., which help mediators to understand the complex phenomena around divorce and mediation. Examples of perceiving tools are the model of the phases of emotional and psychological separation and divorce presented by Lisa Parkinson (2014), the nine-step model of the escalation of conflict by Friedrich Glasl (1999), and the concept of the window of tolerance, introduced by Siegel (1999). These are all tools that help the mediators to understand why the parents find it difficult to communicate with each other or what might help the parents in making a settlement. Depending on mediators' discretion, some of these tools can be shared with parents in mediation sessions when they help also them to conceive their difficulties in communication or in parenting after divorce. 
The technique tools are used in executing the mediation process. They can be tools for communicating about family mediation, for example, leaflets, brochures, referral instructions or process descriptions. An agreement to mediate form was used in the project to communicate to the parents the ground rules of mediation and increase their commitment. They can also be tools for managing the interaction and problem solving in mediation (e.g. different types of questions, techniques for focusing on the child, impasse strategies, re-framing techniques, managing power imbalances, methods for creating options and reality testing).

The most important perceiving tool used in the project was an ecogram, a model introduced by Lisa Parkinson in her training (Parkinson 2014). I will describe it more closely, as it incorporates the main theoretical ideas behind the mediation model created in the project.

During the project, the original figure was adjusted as the participants elaborated the model in the network sessions after Parkinson's training and when testing it in mediation sessions. In project Fasper, the ecogram was drawn as presented in Fig. 3.

The ecogram describes the children and their parents, and the two relationships between the parents: their relationship as a couple now terminated and their relationship as parents that usually needs to continue. The underlying assumption in the project was that it is useful to analytically distinguish these two and to focus family mediation on the parenting relationship and the children. Making this distinction is, however, emotionally difficult for the parents. It is difficult to end the marital or partner relationship yet continue to work together as co-parents (Parkinson 2014). It happens easily and is only human that the disappointments and rows flow into parental issues. That is why the parents benefit from mediators to facilitate their communication and help to overcome the emotional, social and cognitive barriers that are on their way in resolving their conflict (Nylund 2018).

According to the understanding adopted in project Fasper, family mediation is not about who did wrong in the couple relationship. Instead, family mediation is about children's matters and the organisation of their everyday life so that they could

Fig. 3 The ecogram (adapted from Lisa Parkinson 2014)

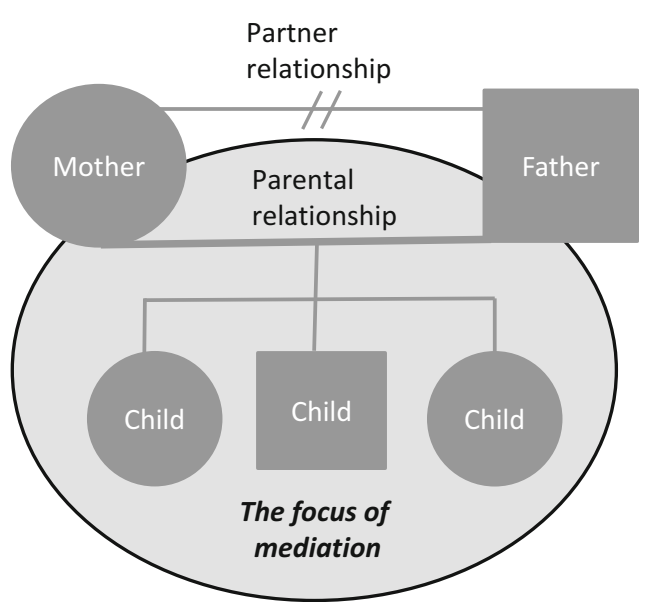


preserve close relationships with their both parents. This idea is encapsulated in the ecogram-as are the best interests of the child as a paramount foundation (see also Bernt 2018; Nylund 2018; Salminen 2018). When serving as a perceiving tool, the ecogram helps both the parents and mediators to keep this in mind. For this, mediators regularly draw the ecogram of the family on a flip-chart at the beginning the mediation process. To make the idea even more concrete, the mediators ask in the preliminary separate meetings of the parents to bring children's photographs when they come to the joint sessions. Then the mediators stick the photos on the ecogram on the flip-chart so that the children are made visible (Haavisto et al. 2014).

The experiences from the mediation experiments showed that when the ecogram was drawn on the flipchart, it started to serve also as a technique tool (Haavisto et al. 2016). Firstly, drawing the ecogram put the parents on the same map right at the beginning of the mediation. Secondly, it served as a memory to help the mediators keep in mind the names of the family members. Thirdly, the ecogram was a powerful tool in demonstrating for parents the entangling of the two relationships and that even though they are disconnecting themselves as partners, they still connect themselves as co-parents. Fourthly, the mediators could use the ecogram as a tool for facilitating the discussion. If the parents continued to talk about their unresolved marital conflicts, the mediators could point to the drawing on the flip-chart and redirect them back to children's issues (Haavisto et al. 2016, see also Parkinson 2014).

\subsection{The Service Model for Organising Family Mediation in a Multi-Organisational Network}

Previously in Finland, family mediation could be organised in municipalities so that workers in family counselling units or other workers of social welfare were appointed to the task. Especially in small municipalities this led to problems with disqualified mediators, as they might have been working with the same family or some of the family members earlier. Another problem was that the individual appointed mediators worked alone without support.

In project Fasper, we developed a multi-organisational model for providing family mediation services (Fig. 4). The stimulus for this was that on one of our piloting areas, three municipalities decided to set up a common unit for family law matters. This meant that family law services-child welfare supervisors confirming the child custody agreements-were provided in one unit for inhabitants of all these three municipalities. The new unit served as a natural base also for family mediation services which would be provided in collaboration by the three municipalities, the family counselling units of the church and authorised NGOs.

In the model, the client contacts the coordinator working at the unit for family law matters, who then appoints the mediators and fixes the timetables. The unit holds a "mediator reserve" - a certain number of trained mediators who have their main job 


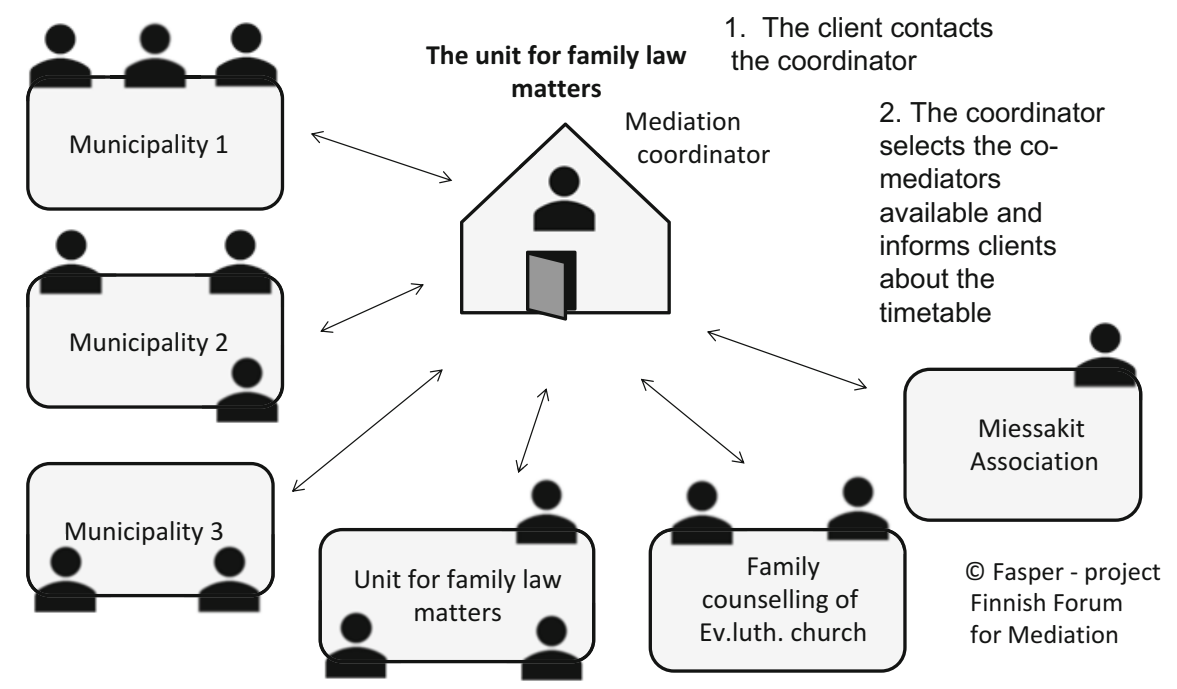

Fig. 4 The multi-organisational model for organising family mediation service

in the organisations belonging to the network. Instead of working as full-time mediators, they have an assignment from their employer to do mediation, for example, $60 \mathrm{~h}$ per year.

One advantage of the model is that it solves the disqualification problems effectively. If the clients come from Municipality 1, the coordinator can select for them mediators who work full-time in Municipality 2 or in some other organisation. Another advantage is that the unit for family law matters can also guide and support mediators' work and organise advanced training and competence development for the mediators.

\subsection{The Model for Elementary Training of Family Mediators}

The model for the elementary training for family mediators was created and piloted in 2013. Since then, the training model has kept the same structure, but there have been minor changes in the content. The overview of the content and structure is presented in Fig. 5.

The training model derives from the same theoretical ideas of expansive learning (Engeström 1987) as project Fasper, adjusted to the context of out-of-work training course. The training follows the idea that learning is not only adapting existing knowledge, but also creating new knowledge. When participants enter a training course they adopt new models, practices and tools, which they can use while practicing as a mediator. This is the acquisition of pre-given models, which, by 


\begin{tabular}{|l|l|l|l|}
\hline Training days $\mathbf{1} \mathbf{\&} \mathbf{2}$ & Training days 3 \& 4 & Training days 5 \& 6 & Training days 7 \& 8 \\
\hline $\begin{array}{l}\text { Family mediation - past } \\
\text { and present }\end{array}$ & $\begin{array}{l}\text { Different stages in } \\
\text { divorce }\end{array}$ & $\begin{array}{l}\text { Observations and } \\
\text { experiences in the } \\
\text { practice period }\end{array}$ & $\begin{array}{l}\text { Observations and } \\
\text { experiences in the } \\
\text { practice period }\end{array}$ \\
\hline $\begin{array}{l}\text { Conflicts and dispute } \\
\text { resolution } \\
\text { Divorce as a conflict }\end{array}$ & $\begin{array}{l}\text { How to keep children in } \\
\text { focus }\end{array}$ & $\begin{array}{l}\text { Parents' concerns and } \\
\text { worries / trust } \\
\text { Co-parenting after } \\
\text { divorce }\end{array}$ & $\begin{array}{l}\text { Mediator's identity; } \\
\text { mediators' community } \\
\text { and the competence } \\
\text { development }\end{array}$ \\
\hline $\begin{array}{l}\text { The mediation process } \\
\text { and its phases - an } \\
\text { overview }\end{array}$ & $\begin{array}{l}\text { Acknowledging feelings } \\
\text { Re-framing }\end{array}$ & $\begin{array}{l}\text { Focusing on the details } \\
\text {-focusing on the big } \\
\text { picture }\end{array}$ & $\begin{array}{l}\text { Family law issues in } \\
\text { mediation }\end{array}$ \\
\hline $\begin{array}{l}\text { Starting the mediation } \\
\text { process and individual } \\
\text { preliminary meetings }\end{array}$ & $\begin{array}{l}\text { Preparations and } \\
\text { starting the first joint } \\
\text { meeting } \\
\text { Clarifying issues }\end{array}$ & $\begin{array}{l}\text { Negotiating } \\
\text { Creating options / } \\
\text { brainstorming }\end{array}$ & $\begin{array}{l}\text { Reality testing } \\
\text { The closure of } \\
\text { mediation }\end{array}$ \\
\hline
\end{tabular}

Practice with a co-mediator

Reflections and feedback between the training sections

A travel story - how did I become a mediator

Fig. 5 An overview of the elementary training for family mediators

definition, is the focus in all training. In addition to that we saw it important that the students are encouraged to practice with a real case in between the training sections, either with a more experienced colleague, if they have one, or with another student from the same course. The experiences of the practicing are discussed and elaborated in the training. The personal experience of mediating opens up the possibility to not only adopt the pre-given models, but also to cultivate, enrich and transform them.

The same idea of transformative learning and students' own agency applies with the several role-plays during the course. The training follows the process of mediation: each day focus is on one phase in the mediation process. In the altogether six role-plays during the course, the students are practicing a determined phase of the mediation process and some theme or technique (e.g. re-framing or acknowledging feelings). They are not supposed to solve the conflict in one role-play, but only in the last one.

The theory of expansive learning sees that human activity is culturally mediated by tools and models (Engeström 1987). The idea of a mediator's toolkit was essential also in the training model. Our aim was that during the course we offer the students material from which they can collect themselves a toolkit of appropriate models and techniques to be used. The distinction between perceiving tools and technique tools, presented in an earlier chapter, was applied in the training. 


\subsection{Evaluating the Benefits of the Implemented Family Mediation Model}

The interviews conducted in the 16 family mediation experiments in 2012 give some clues about the benefits of mediation for the families. The information is only tentative, as it is collected in a phase, when the mediators were only practicing the new way of working and many details were still in progress. No longitudinal statistics are thus far available about the possible effects on the service system level.

The first findings gave support to the idea that early family mediation can help parents to agree on their children's issues. The agreements can include solutions that can be confirmed by the child welfare supervisor to be enforceable. They can also include solutions that deal with the everyday details in children's life. The following excerpts describe the variation in the agreements:

In the first meeting, we got an agreement on contact during the summer holiday. The result of the whole mediation process was an agreement on a flip-chart about the custody, living and contact. We went afterwards to see the child welfare officer who confirmed the agreement. The court case that was already pending was withdrawn. A father

I was amazed how small things can help our everyday life. I mean, we defined how often we keep in contact, when the child is with the other parent, and how possible new partners are introduced to the child. And we agreed to have a small notebook for sharing information, and we agreed that we write every evening some sentences of what has been done with the kid, and then the other parent can read it. No need to start guessing what the five-year-old has meant, and no need to question who is right, the child or the adult. I think we succeeded to get our mutual trust on a new level. All in all, we talked quite much about trust. It was something we never couldn't discuss by ourselves. A father

Often mediation breaks the silence between the parents or cuts the circle of quarrelling, and helps to listen to each other's thoughts. This, in turn, helps to decrease the de-humanisation between the parents and encourages them to see each other as people who want best for their children. The most positive feedback for the mediators was given for preventing parents from fighting about their old marital conflicts and focus firmly on the child. It seems that parents approve mediators' active and even strict role in guiding the conversation when it supports the parents to communicate more constructively in children's matters and in getting things agreed.

Maybe I went there to talk about our divorce. It was not so clear to me that in mediation, we think about the child. It appeared to be very good, cause many problems, even the practical ones, are resolved when we focus on the child. The child has been, anyway, our bone of contention. A mother

I think they [the mediators] succeeded very well in calming us down. If the conversation got too heated, they said 'time out' and handled it very well. A mother

The best thing was that the mediators always took the discussion back to the children. Every time we got out of it, they somehow put it back and brought in the viewpoint of the children. It really hit home for me a couple of times there. A father 
I got gradually convinced that after all also the father wants best for the kids, and I could also say that to our children after the mediation. A mother

Early family mediation is, to a large extent, supporting the parents towards responsible parenting after their divorce. Managing conflicts is part of responsible parenting that can be supported in mediation. Many parents seemed to recognise their new, more responsible thinking as an important result of the mediation. Even though the parents could not make any agreement, they could still see some positive effects of the mediation process on the everyday life of the child (see last excerpt below). In this sense, mediation becoming more common may shape our contentious divorcing culture to a direction that better recognises children's needs.

The biggest effect was that it [mediation] made us think that if things go on like this, where does it lead. This really must end. The child is suffering from this. A mother

I think that from now on, I think more carefully what are the consequences of my own behaviour. A father

Our elder daughter is going to school in the neighbouring city, where also her father has his workplace. Now [after the mediation process] the father has spontaneously called in the mornings and offered her a lift, so that they can travel together. A mother

Family mediation is relatively inexpensive. In the project, it was estimated that a mediation process for one family takes approximately $10 \mathrm{~h}$. This includes the individual preliminary meetings (45 min each), three joint sessions (90 min each), a possible follow-up session and time for planning and reflection between the co-mediators. Recently, the cost of a working hour in demanding professional work in social welfare has been estimated to be 75 euros (Hämäläinen 2011). Following this, the costs of mediation for one family would be 1500 euros with two mediators. The number is, however, an educated estimate, as mediation executed as a part of public office does not directly increase salary or other costs in the municipality.

What it requires, however, is new thinking in allocating the services. Family mediation could be offered to some parents instead of long-lasting counselling. In many cases, a short-term, structured procedure could be enough to help the parents get forward. We also believe that family mediation can be regarded as proactive child protection, which may prevent conflict escalation. In the future, it is important to investigate whether investing on early family mediation could decrease the number of child welfare notifications related to conflicted divorces, ease work pressure in family counselling and child protection or decrease the number of child custodies by the authorities. 


\section{Conclusions}

Project Fasper showed that producing new understanding and conceptualisations of mediation is in a constant interplay with the more tangible changes in practices-in fact, they are two sides of the coin (Haavisto et al. 2016). While trying to understand what family mediation is about, the participants produced conceptualisation of family mediation, which received practical manifestations in the forms of models, artefacts, documents or structures of social organisation. Respectively, while tackling the mundane questions of practical details in the mediation service, the participants produced joint understanding of mediation.

The potential for novel practices and creating new knowledge-learning something that is not yet there-is in the core of the theory of expansive learning (Engeström 1987). The developmental work done in project Fasper suggests not to forget the importance of learning as adopting. For example, many of the mediators' new tools represented the acquisition of existing knowledge. Some of them were adopted from existing theories as such; some of them were adopted after alterations through re-defining and re-considering the context of use (Haavisto et al. 2016). What was fundamental was the constant alternation and interplay in the project between adopting existing knowledge and creating new knowledge. Because of this interplay, the adopting of existing knowledge resembled "making things one's own". The models and tools acquired in the mediation training, as well as the ways of using them, were collaboratively adjusted and cultivated to fit the local needs.

The alternation of the two forms of learning is visible also when all the phases of the project are considered. In the active years of the local development in the network sessions (approximately 2010-2013), the prevailing form of learning was the creation of new practices with the support of the family mediation training and adoption of existing models. After that, the focus has been in the organisation of an elementary training for family mediators and expanding the locally created models and practices nationwide (from 2014 onwards). Now the locally created models of project Fasper are pre-given knowledge to be adopted by family mediators in other municipalities. Still, the adoption of pre-given knowledge needs to be supported by local development and adjusting, wherever the models are implemented.

Regarding the implementation of change, project Fasper represented bottom-up implementation with its starting point in local development of new models and practices. Nevertheless, implementation of change is hardly ever a process of only one direction. In project Fasper, developmental process was not merely a local, grassroot contribution without any preconditions or limits. The ruling given in the Marriage Act set one prerequisite for the development, although diffuse. Correspondingly, family mediation was an existing part of Finnish service system for divorcing couples, even though it was diffused and unclear in its content. The elements of top-down implementation were intertwined with the bottom-up development. The existing concept-family mediation-was interpreted, enriched and concretised in ways that went beyond pre-given models. This supports a 
complementary view on implementation as a learning process with a significant potential for expansion.

The interplay of top-down and bottom-up implementation of change is also essential when viewing the larger picture of the consolidation of the implemented practices. The developmental project solved the local problems of organising family mediation, but, at the same time, disclosed the urgent need to unify the national prerequisites and top-down governing of family mediation. In addition to local guidelines and codes of conduct, also national, permanent infrastructure for supporting, guiding and supervising family mediation is needed-including the necessity to revise the legislation.

Top-down consideration is needed also in dispute systems design when the dispute resolution processes available for divorcing parents are viewed as a unity. As Nylund (2018) calls for, the different mediation services should be clearly distinguished from each other, and the differences between them appropriately explicated. Thus far, there has been no administrative or legal articulation concerning the prioritized sequence of municipal family mediation and the courtconnected mediation in custody disputes. Although the dispute system should ideally consist of levels that build on the lower one and include a return mechanism (Nylund 2018), the reality is now that parents may enter family mediation after trying court-connected mediation or after having a court order in custody dispute. Similarly, there is no articulation about the differences in the aims, content, and the role of mediators between these two forms of mediation. A top-down dispute system design and articulation is needed to support the parents, as well as the professionals, in accessing the most appropriate dispute resolution alternative in each case.

Project Fasper was a collaborative effort to reform family mediation and create new conceptualisations, models and practices. It was an example of the possibilities and challenges of local learning and multi-view developmental work. From now on, it is important to continue the local developmental work, but also to take care of the prerequisites of family mediation on the national level and consider the totality of the dispute system. The efforts of those participating in the project were possibly an overture for a future sea-change in family mediation. The joint effort put the ball rolling, but no one can foresee where it will stop.

\section{References}

Bardach E (1980) The implementation game: what happens after a bill becomes a law, 3rd edn. MIT Press, Cambridge

Bergman-Pyykkönen M (2017) Towards interprofessionality in developing family mediation in Finland. Soc Work Educ 36(5):575-590

Bernt C (2018) Custody mediation in Norwegian courts: a conglomeration of roles and processes. In: Nylund A, Ervasti K, Adrian L (eds) Nordic mediation research. Springer, Cham, p 105-132

Eduskunnan oikeusasiamiehen päätös (2004) Havaintoja vanhempien välisiin ristiriitoihin tarjolla olevista sovittelu- ja neuvontapalveluista lapsiin liittyvissä kysymyksissä. Dnro 2059/2/03 
Eisenstein J, Flemming RB, Nardulli PF (1988) The contours of justice: communities and their courts. Little, Brown and Company, Boston

Engeström Y (1987) Learning by expanding. An activity-theoretical approach to developmental research. Orienta-Konsultit, Helsinki

Engeström Y (1995) Kehittävä työntutkimus. Perusteita, tuloksia ja haasteita. Hallinnon kehittämiskeskus, Helsinki

Engeström Y (2005) Developmental work research. Expanding activity theory in practice. Lehmanns Media, Berlin

Engeström R (2009) Who is acting in an activity-system? In: Sannino A, Daniels H, Gutiérrez K (eds) Learning and expanding with activity theory. Cambridge University Press, New York, pp 257-273

Engeström Y (2014) Collective concept formation as creation at work. In: Sannino A, Ellis V (eds) Learning and collective creativity. Activity-theoretical and sociocultural studies. Routledge, New York, pp 234-257

Engeström Y, Sannino A (2010) Studies of expansive learning: foundations, findings and future challenges. Educ Res Rev 5(1):1-24

Engeström Y, Sannino A (2012) Concept formation in the wild. Mind Cult Act 19(3):201-206

Glasl F (1999) Confronting conflict. A first-aid kit for handling conflict. Hawthorn Press, Gloucestershire

Greeno JG (2012) Concepts in activities and discourses. Mind Cult Act 19(3):310-313

Haavisto V (2002) Court work in transition. An activity-theoretical study on changing work practices in a Finnish district court. University of Helsinki, Department of Education, Helsinki. https://helda.helsinki.fi/handle/10138/19754. Accessed 1 July 2017

Haavisto V, Bergman-Pyykkönen M, Karvinen-Niinikoski S (2014) Perheasioiden sovittelun uudet tuulet. Havaintoja, mallinnuksia ja arvioita FASPER -hankkeen pohjalta. Suomen sovittelufoorumi ry, Helsinki

Haavisto V, Bergman-Pyykkönen M, Karvinen-Niinikoski S (2016) Käsitteenmuodostus käytäntöjen kehittämisessä: tapausesimerkkinä perheasioiden sovittelu. In: Satka M et al (eds) Käytäntötutkimuksen taito. Heikki Waris -instituutti ja Mathilda Wrede -institutet, Hämeentie, pp 99-134

Hämäläinen J (2011) Kalliit erot. Selvitys huoltoriitojen kustannuksista. Lastensuojelun keskusliitto. Neuvokeskus, Helsinki

Hutchins E (2012) Concepts in practice as sources of order. Mind Cult Act 19(3):314-323

Julkunen I, Karvinen-Niinikoski S (2014) Socially robust knowledge processes of local and global interest in social work. In: Harrikari T, Rauhala P-L, Virokannas E (eds) Social change and social work. The changing societal conditions of social work in time and place. Ashgate, Farnham, pp 101-120

Karvinen-Niinikoski S, Pelli M (2010) Perheasioiden sovittelu - riitelykulttuurista vastuulliseen osallisuuteen. In: Poikela E (ed) Sovittelu. Ristiriitojen kohtaamisesta konfliktien hallintaan. PS-kustannus, Jyväskylä, pp 91-108

Leontjev AN (1978) Activity, consciousness and personality. Prentice Hall, Englewood-Cliffs

Lewin K (1948) Resolving social conflicts: selected papers on group dynamics. Harper \& Brothers, New York

Mahkonen S (2008) Perhesovittelu. Selvitys avioliittolaissa 1987 säädetystä perheasioiden sovittelusta lähtökohtana lapsen aseman turvaaminen vanhempien erossa. Lastensuojelun Keskusliiton Neuvo-projekti

Majone G, Wildavsky A (1984) Implementation as evolution. In: Pressman J, Wildavsky A (eds) Implementation, 3rd edn. University of California Press, Berkeley

Mattila-Aalto M, Bergman-Pyykkönen M, Haavisto V et al. (2012) Konfliktiteoreettinen näkökulma eroihin ja palvelujen kehittämiseen. In: Kääriäinen $\mathrm{A}$, Hämäläinen J, Pölkki P (eds) Challenges of divorce, interventions and children. Eron haasteet, väliintulot ja lapset. Ensi- ja turvakotienliiton julkaisu 39, pp 213-241

Mazmanian DA, Sabatier PA (1983) Implementation and public policy. Scott Foresman, Glenview 
Nylund A (2018) A dispute system design perspective on Norwegian child custody mediation. In: Nylund A, Ervasti K, Adrian L (eds) Nordic mediation research. Springer, Cham, p 9-26

Palumbo DJ, Calista DJ (1990) Opening up the black box: implementation and the policy process. In: Palumbo DJ, Calista DJ (eds) Implementation and the policy process. Opening up the black box. Greenwood Press, Westport, pp 3-18

Parkinson L (2014) Family mediation, 3rd edn. Jordan Publishing Limited, Bristol

Pressman JL, Wildavsky A (1984) Implementation, 3rd edn. University of California Press, Berkeley

Roberts M (2008) Mediation in family disputes. Principles of practice, 3rd edn. Ashgate, Aldershot Salminen K (2018) Is mediation in the best interest of a child from a child law perspective? In: Nylund A, Ervasti K, Adrian L (eds) Nordic mediation research. Springer, Cham, p 209-222

Siegel DJ (1999) The developing mind. How relationships and the brain interact to shape who we are. Gilford Press, New York

Toimiva lastensuojelu -selvitysryhmän loppuraportti (2013) Sosiaali- ja terveysministeriön raportteja ja muistioita 2013:19

Vindeløv V (2007) Mediation. A non-model. Jurist- og Økonomforbundets Forlag, Copenhagen

Vygotsky LS (1978) Mind in society. The development of higher psychological functions. Harvard University Press, Cambridge

Yanow D (1990) Tackling the implementation problem: epistemological issues in implementation research. In: Palumbo DJ, Calista DJ (eds) Implementation and the policy process. Opening up the black box. Greenwood Press, Westport, pp 213-228

Open Access This chapter is licensed under the terms of the Creative Commons Attribution 4.0 International License (http://creativecommons.org/licenses/by/4.0/), which permits use, sharing, adaptation, distribution and reproduction in any medium or format, as long as you give appropriate credit to the original author(s) and the source, provide a link to the Creative Commons license and indicate if changes were made.

The images or other third party material in this chapter are included in the chapter's Creative Commons license, unless indicated otherwise in a credit line to the material. If material is not included in the chapter's Creative Commons license and your intended use is not permitted by statutory regulation or exceeds the permitted use, you will need to obtain permission directly from the copyright holder.

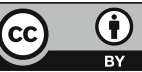

